\title{
A class of analytic inequalities involving $n$ positive numbers
}

YU-DONG WU, ZHI-HUA ZHANG and ZHI-GANG WANG

\section{ABSTRACT.}

In this paper, by using the theories of Schur-concave function and classical analysis, we give a class of analytic inequalities which settle affirmatively to several open problems posed by Sun.

DEPARTMENT OF MATHEMATICS

ZHEJIANG XiNCHANG High SCHOOL

SHAOXING,ZHEJIANG 312500

PEOPLE'S REPUBLIC OF CHINA.

E-mail address: yudong.wu@yahoo.com.cn

DEPARTMENT OF MATHEMATICS

SHILI SENIOR HigH SCHOOL IN ZIXING

CHENZHOU, HunAN 423400

PEOPLE'S REPUBLIC OF CHINA.

E-mail address: zxzh1234@163.com

SCHOOL OF MATHEMATICS AND STATISTICS

ANYANG NORMAL UNIVERSITY

ANYANG, HENAN 455002

PEOPLE'S REPUBLIC OF CHINA.

E-mail address: zhigwang@163.com 